\title{
Architekt jako synergetyk
}

\section{J.-Krzysztof Lenartowicz}

Samodzielna Pracownia Architektoniczna, Wydział Budownictwa i Architektury, Politechnika Lubelska; Wydziat Architektury, Politechnika Krakowska; Sekcja Teorii Architektury, Komisja Urbanistyki i ArchitekturyPAN OddziatwKrakowie, e-mail: j.lenartowicz@pollub.pl

Streszczenie: W artykule przedstawiono krytyczną analizę zmieniającego się w czasie zakresu działania i statusu architekta, ze zwróceniem uwagi na obecną sytuację w Polsce. Witruwiański Architectus zakresem działania sięgał od planowania miast po budowanie zegarów; obowiązywała go cała wiedza inżynierska. Architektura traktowana była jako Matka Sztuk. Owocem syntezy sztuk był dziewiętnastowieczny Gesamtkunstwerk. Jeszcze Żórawski (1961) pisał o organicznej więzi architektury z innymi sztukami. Le Corbusier (1929) definiował architekturę jako grę brył w świetle. Dzisiaj ogarnięcie całości dyscypliny przez pojedynczą osobę jest niemożliwe. Zawód architekta zaczął się rozszczepiać i specjalizować. $\mathrm{Z}$ architektów wyrośli urbaniści, konstruktorzy, architekci krajobrazu, ekologowie, ostatnio nawet pośrednicy między interesariuszami (użytkownikami i zespołem projektowym) służący behawioralnej interwencji publicznej - wszyscy z architekturą powiązani. Do niezbędnego zakresu analizy doszły zagadnienia środowiskowe wszelkiego rodzaju (przyrodnicze, społeczne, zawodowe, prawne), ekologiczne i ekonomiczne. Samo projektowanie otrzymało komputerowe narzędzia koordynacyjne, modelujące, kreślarskie i prezentacyjne.

Zarysowano proces zmian w okresie 2014-2018 w dotyczącym kształtowania przestrzeni polskim ustawodawstwie. Przedstawiono pozycję architekta w Polsce dzisiaj, który jako urbanista, został zdelegalizowany (2014), jako architekt istnieje w izbie samorządu, ale nie panuje nad innymi sztukami. W ustawie Kodeks Urbanistyczno-Budowlany (2017) nie wspomina się architekta. Praktyka budowania potwierdza zaniechanie synergicznego rozumienia zawodu, upadek twórczości i odpowiedzialności moralnej przedstawicieli nominalnie zawodu zaufania publicznego. Samo słowo „,architektura” używane jest dziś przez dziennikarzy w skrajnie negatywnych określeniach dotyczących sytuacji politycznych czy gospodarczych, co wypacza istotę rozumienia pojęcia architektura.

Przywrócenie niezbędnej synergetyczności działaniom w przestrzeni według autora wymaga prawnie umocowanej i skutecznie realizowanej partycypacji świadomych obywateli tworzących społeczeństwo obywatelskie jako partnera w dialogu niezbędnym dla uzyskania jakości.

Słowa kluczowe: zawód architekta, definicja architektury, sztuki plastyczne, prawo, piękno.

\section{Wprowadzenie}

Zamiarem autora jest przedstawienie roli architekta i faktycznego zakresu możliwości jego działania, w aspekcie zmian jakie następowały i następują w czasie. Fakty świadczą o odchodzeniu od wielowartościowego rozumienia synergetycznej roli architekta jako tego, kto zajmuje się kształtowaniem środowiska człowieka. Konsekwencją tych zmian jest 
tendencja do zawężania pozycji architekta w aktualnym polskim prawodawstwie. Nie można też nie zauważyć samo-poddawania się architektów w wyniku obniżenia kompetencji, tj. braków wiedzy (edukacja) i umiejętności (praktyka), a także osłabienia postawy moralnej (odpowiedzialność).

Na początku należy postawić pytanie, jak rozumieć tytułowy związek pojęcia architekta jako zawodowca z pojęciem synergii. Pozytywna odpowiedź wymaga udowodnienia, że w działaniu zawodowym architekta występuję efekt synergii, tj. pomnażania efektów w wyniku aglomerowania składników i to pomnażania rzeczywistego, które nie wynika li tylko z prostego ich (tych składników) dodawania. Oczywiście trudno ująć to liczbowo, gdy zamiar dotyczy panoramy dziejów. Autor przegląda historię i wyłuskuje bardziej znaczące, jak się wydaje, przykłady.

Rozumienie architektury zawsze obejmowało więcej niż pojedynczą rzecz, czy pojęcie. Zanim ktoś podał termin 'architektura', działało określenie: budowanie. Od zarania dziejów ludzie mieli potrzebę urządzania sobie schronów dla umożliwienia przeżycia w otoczeniu natury. Niekiedy jaskinie oferowały schronienia gotowe do zamieszkania. Jednak przy osiadłym trybie życia, świadome tworzenie własnego środowiska życia dawało pewniejsze rezultaty; stąd budowanie, w różnych formach, zależnych przede wszystkim od stojących do dyspozycji materiałów, zaczęło dominować nad przypadkiem. W budowaniu niektórzy doszli do wielkiej biegłości i obok oczekiwanego spełnienia podstawowych potrzeb, zauważono możliwość tworzenia rzeczy, które nie tylko są praktyczne, ale także się podobają. Przyjmijmy, że to wówczas budowle, będące owocem budowania, zaczęto nazywać architekturą. Mamy więc wartość dodaną - użyteczność + piękno, co w sumie daje lepszy produkt. Przez wieki zakres, który dotyczy architektury, w którym ona się mieści, albo który przekracza, był różnie określany. Samo bycie architektem (budowniczym) również w różnej mierze nobilitowało. Architekci należeli i sami się zaliczali do elity społeczeństwa.

Co się teraz stało z powszechnym społecznym widzeniem tego zawodu? Co z profesjonalną odpowiedzialnością za skutki swoich działań? Przedstawiono cztery hipotetycznie wyodrębnione fazy opisujące pozycję i rolę architekta, od legendarnego demiurga, przez wszechstronnego projektanta, członka zespołu projektodawczego, po ubezwłasnowolnionego sługę inwestora. wszechstronnego projektanta, członka zespołu projektodawczego, po ubezwłasnowolnionego sługę inwestora. Na koniec przedstawiono sytuację w Polsce w XXI w.

\section{Faza I legendarna, pan-energetyczna. Architekt demiurg}

Twórca piramidy schodkowej w Sakkarze Imhotep (ok. 2650-2600 p.n.e.), de facto wynalazca piramidy w ogóle, wezyr na dworze faraona Dżosera z III dynastii, zasłużony dla medycyny lekarz, ale też i pierwszy znany z imienia architekt, był za życia czczony jako geniusz, z tytułami m.in. "Budowniczego" i "Rzeźbiarza”. Dwa tysiące lat po śmierci (a więc dwadzieścia sześć wieków temu) Egipcjanie zaczęli oddawać mu cześć boską. O ile wiadomo, jest on jedynym jak dotąd architektem w gronie bogów.

W średniowiecznych cechach kamieniarskich do Boga, stworzyciela nieba i ziemi, odnoszono się jako do Twórcy. Później, w XVII w. w lożach masońskich uznawano istnienie Bóstwa, Absolutu (odpowiednika platońskiego Demiurga), nazywanego Wielkim Budowniczym (Architektem) Wszechświata.

Faza I to przykłady skrajnie szerokiego, zahaczającego o metafizykę, określenia możliwości i zakresu działania architekta. Trudno zaprzeczyć synergetycznemu charakterowi 
działania osób o najwyższym transcendentnym statusie, obdarzonych boską wszechmocą i reprezentujących zawód zwany architekturą, którego reguły otoczone są tajemnicą. Nazwa architekt odnosi się w tym przypadku do kogoś, kto ma moc i umiejętność tworzenia, w domyśle - tworzenia rzeczy wielkich. Blask, który towarzyszy takiemu rozumieniu architekta, jest i dzisiaj, często podświadomie, motorem napędzającym zgłaszanie się na studia architektoniczne.

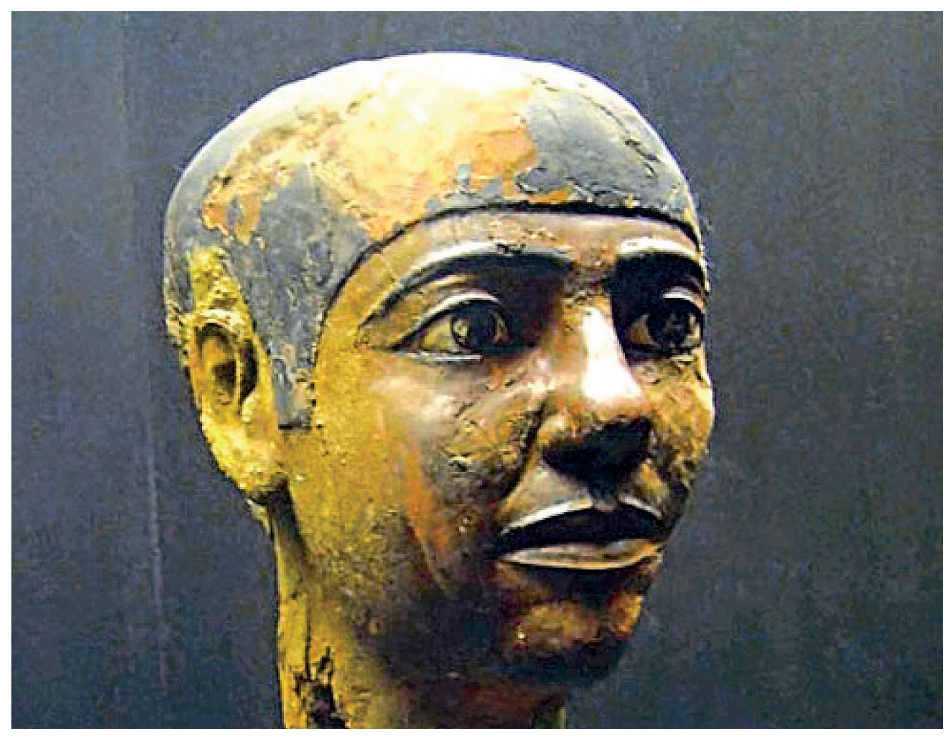

Il. 1. Imhotep. Rzeźba w Muzeum Imhotepa, Sakkara. Fot.: Internet

\section{Faza II synergetyczna. Fachowiec wielostronny i artysta}

Witruwiusz (1956), żyjący 25 stuleci po Imhotepie, opisał praktyczny zakres dziedziny architektury w I w. p.n.e. Sam był inżynierem i to wojskowym - saperem. Określił obowiązki architekta, którego zakres działania, sięga od budowania miast po budowanie zegarów. W środku tej skali są budynki, śluzy, mosty i inne drobniejsze urządzenia techniczne. Architekta obowiązywała cała ówczesna wiedza inżynierska. Obok szerokiego zakresu wiedzy i działań, praca architekta dotyczyła w każdym przypadku zapewnienia użyteczności - czyli dobrego działania (funkcjonowania), bezpieczeństwa - czyli trwałości produktu, ale też tego co ulotne, żeby się ten produkt zarazem podobał. Takie rozumienie trwało przez wieki. Jeszcze na przełomie belle epoque architekci finalizowali swoje inżynierskie wykształcenie politechniczne w akademiach sztuki, czy to w Wiedniu, czy w Petersburgu, a w Polsce po I wojnie światowej - na Wydziale Architektury ASP w Krakowie. Mieli status inżyniera-artysty.

Wkrótce po I wojnie światowej Le Corbusier (1923) zdefiniował architekturę jako grę brył w świetle, i chociaż dodawał, że ta gra ma być mądra (oparta na wiedzy, mistrzowska), bezbłędna (właściwa, poprawna) i wspaniała (w tym sensie - piękna) (l'architecture est le jeu savant, correct et magnifique des volumes assamblés sous la lumière), ograniczał ją zasadniczo do formy widzialnej. Znane są też jego propozycje socjologiczne, mające na celu zaspokojenie traktowanych w sposób zunifikowany potrzeb mieszkaniowych wielkich mas społecznych dzięki podaży 'maszyn do mieszkania'. 


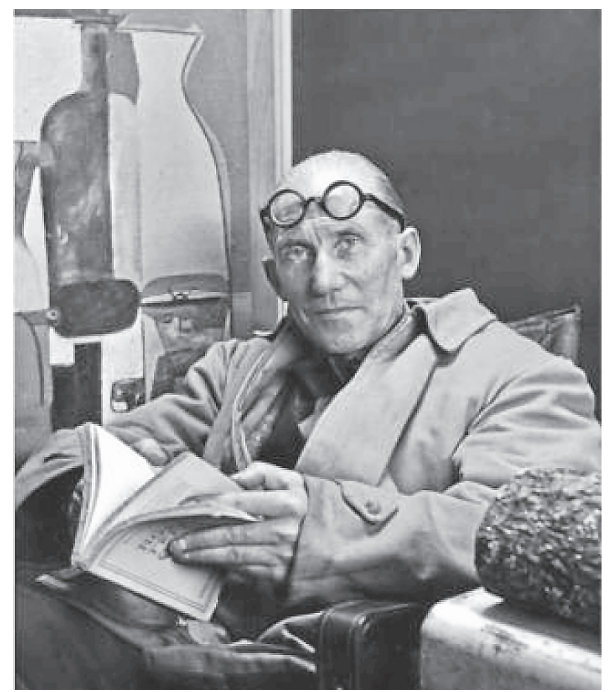

Il. 2. Le Corbusier. W tle obraz jego pędzla. https://www.wikiart.org/en/le-corbusier - 30 lipca 2017; 14:16

Nie powinniśmy odrzucać kategorii modernistycznej architektury, które obok walorów estetycznych opartych na corbusierowskiej grze brył w świetle, regulowały również zasady funkcjonalno-przestrzenne osiedli, zgodnie z ustaleniami Karty Ateńskiej (1933), które dzisiaj niektórzy traktują za przeżytek.

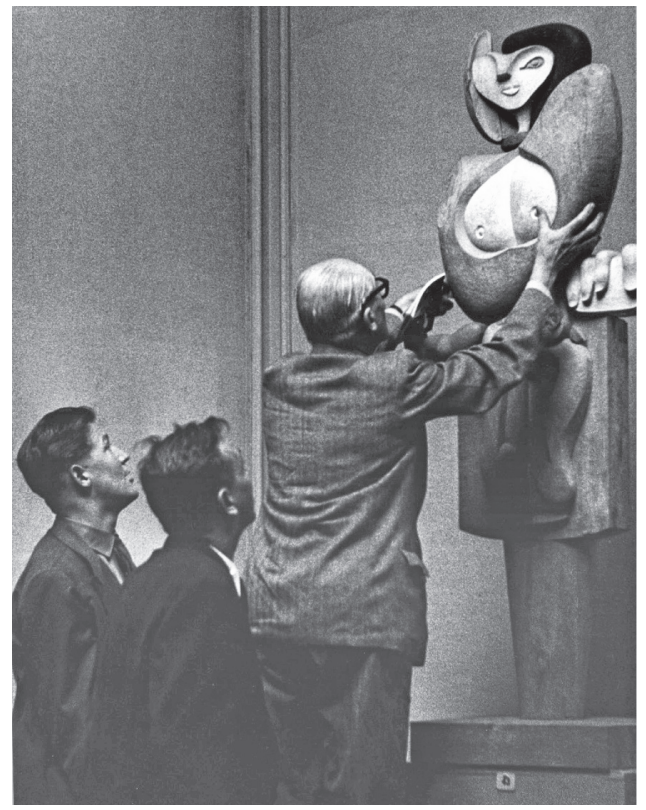

Il. 3. Le Corbusier ustawiający swoją rzeźbę $L a$ Femme. http://www.telerama.fr/scenes/le-corbusier-1-architecte-mesure-au-metre-carre,126062.php - 30 lipca 2017; 14:25

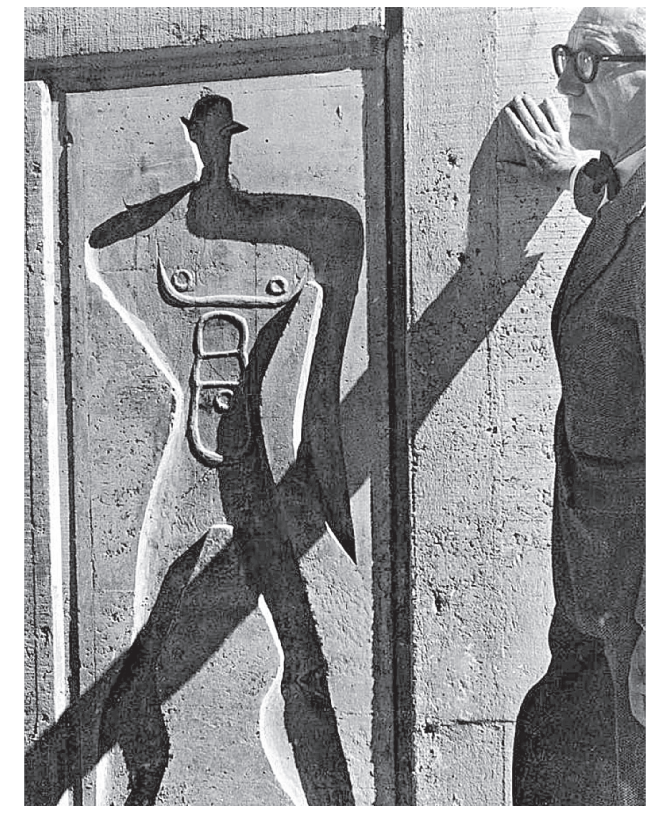

Il. 4. Le Corbusier-Modulor, Jednostka Marsylska. http://larepubliquedeslivres.com/le-corbusier-ou-loeil-de-larchitecte/ - 30 lipca 2017; $15: 16$ 
W przeszłości architektura traktowana była jako Matka Sztuk, dziedzina integrująca budowanie z malarstwem i rzeźbą. O organicznej więzi architektury z innymi sztukami pisał jeszcze pół wieku temu Żórawski (1961) w eseju „Rzeźba-architektura-malarstwo. Problematyczna geneza". Owocem syntezy sztuk był dziewiętnastowieczny Gesamtkunstwerk Ryszarda Wagnera, Gottfrieda Sempera i innych współpracujących twórców różnych dziedzin sztuki - zamierzenie prawdziwie synergetyczne. Oczywiście odwieczne estetyczne zainteresowania architektów formą widzialną, postrzeganą przez aparat wzrokowy człowieka pozostają nadal aktualne. Temu dawał wyraz Juliusz Żórawski korzystający z osiągnięć psychologii postaci dla wyjaśnienia warunków odbioru formy architektonicznej i jej budowy (Żórawski 1962a). Tak też rozumiał syntezę sztuk Le Corbusier i wielu innych po nim. Berthold Lubetkin w rozkwicie modernizmu wstawił w domu mieszkalnym kariatydę żywcem wziętą z Erechtejonu. Le Corbusier, architekt, rzeźbiarz i malarz, był symbolicznie ostatnim demiurgiem, który jeszcze samodzielnie decydował, polegając na własnym rozumowaniu, wiedzy, umiejętności i sztuce tworzenia.

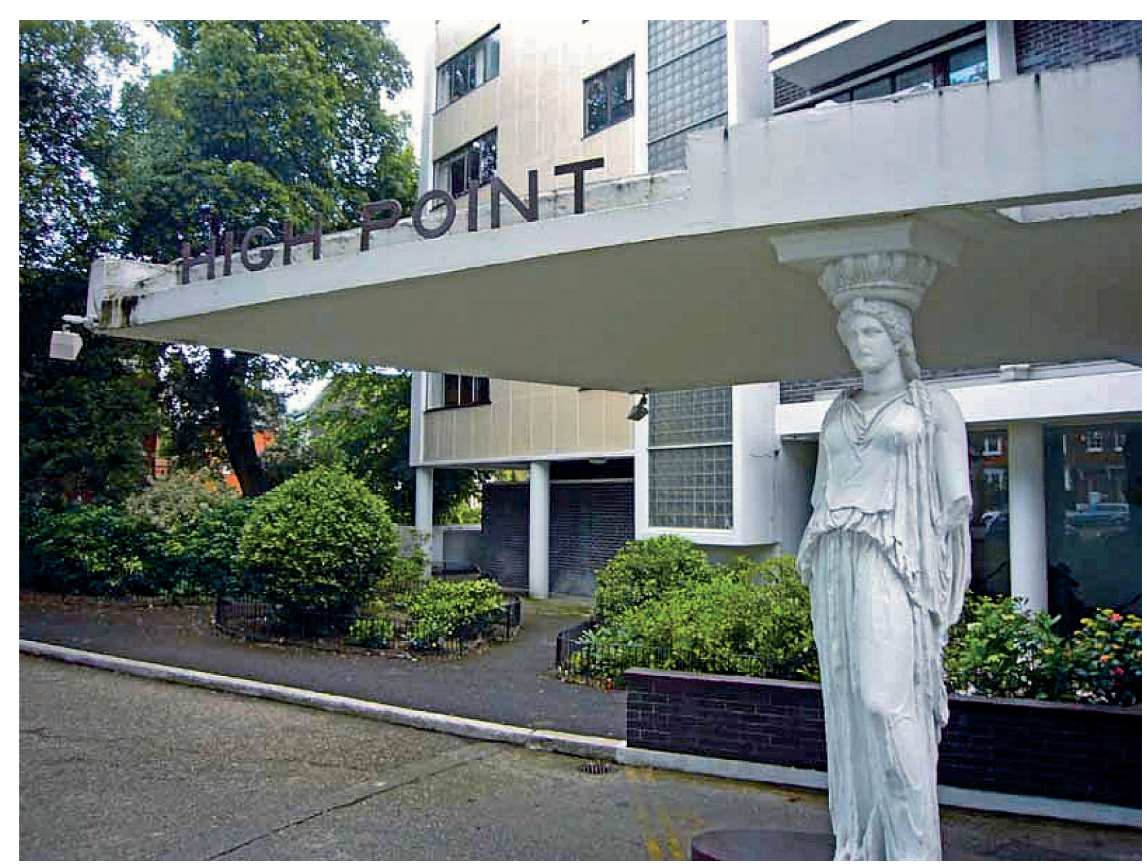

Il. 5. London, zespół mieszkaniowy Highpoint I, Highgate, Berthold Lubetkin (TECTON), 1935. Photo C Adrian Welch, Sep 2011

Podsumowując można określić fazę II jako okres należący do architekta inżyniera, rzeczywiście synergetyka wielu dziedzin, które musi opanować. Wśród nich są dziedziny czysto artystyczne, w których musi się sam poruszać. Jest wirtuozem grającym na wielu instrumentach, dążącym do integracji sztuk, fachmanem od dobrej roboty umiejętnie wykonywanej. Zachowuje postawę demiurga, ale jest też żywym członkiem społeczeństwa. Jako Witruwiusz umie projektować miasto, dom i zegar. Symbolicznie tę fazę określa Le Corbusier, który zajmuje się architekturą, rzeźbą i malarstwem. 


\section{Faza III. Rozszczepienie roli architekta przez specjalizację. Synergia działania wielu aktorów}

Rewolucja przemysłowa, przyrost ludności przyczyniły się do dywersyfikacji pracy w dziedzinie dotąd określonej jako architektura. Pojawiły się nowe typy budowli (np. hale fabryczne), nowe rodzaje zespołów budowlanych (np. dzielnice i zakłady przemysłowe), rozrastały się miasta.

W XX w. wyodrębnił się zawód urbanisty. Le Corbusier (Le Corbusier 1924) określił dziedzinę dotąd należącą do architektury, a planiści i projektanci miast i osiedli stworzyli osobną grupę architektów-urbanistów. Potrzeba odbudowy po zniszczeniach wojny światowej i budowy nowych mieszkań spowodowała ten podział zawodu. Potrzebni stali się zresztą nie tylko twórcy-artyści, ale również architekci-urzędnicy regulujący sposób zabudowy, pilnujący porządku prawnego i dzięki niemu - również ładu przestrzennego. Rosła administracja, architekci po drugiej stronie, jako urzędnicy zajęli trudne stanowiska - trudne, bo leżące po stronie władzy, władzy wykonawczej, co zawsze tworzy różnego rodzaju pokusy, zarazem formalnie odcina możliwość tworzenia.

Jeszcze pół wieku temu Żórawski (1962b) pisał, że: „Z wszystkich dziedzin architektury jako pierwsze urbanistyka i konstrukcja oparły się całkowicie na zdobyczach współczesnej nauki. O ile w dobie renesansu w Italii lub w państwie Khmerów nastąpiło zrównanie między architektem a rzeźbiarzem, w tej chwili jest pewne, że znakiem równości można połączyć trzy bliskie sobie zawody: architekta, urbanisty i konstruktora. Dziś najwybitniejsi architekci są konstruktorami, a najwybitniejsi konstruktorzy - architektami. Takim jest Włoch [Pier Luigi] Nervi i Finlandczyk[!] Alvar Aalto.” Dziś wiemy, że dziedzina konstrukcji usamodzielniła się i wyodrębniła z architektury. Dotąd intuicyjnie lub metodą prób i błędów realizowane przez samych architektów-budowniczych zadania, konstruktorzy poczęli obliczać. Obowiązujące prawo zabrania tego architektowi. Stworzono metody modelowania pracy ustrojów budowlanych na papierze, bez ryzykowania katastrofy na miejscu budowy. Polegające na proporcji określenie wysokości belki w stosunku do jej rozpiętości (pomiędzy kolumnami), znane ze starożytnej Grecji, zostało zastąpione obliczeniami bardziej precyzyjnymi, a i materiał - kamień, czy cegła, został zastąpiony hybrydą - mieszaniną kruszonego kamienia i cementu, z zatopionymi prętami stalowymi. To nawet dla specjalistów jest nadal pole badawcze. Architekci oddali pole w tym zakresie.

W czasach nam współczesnych ogarnięcie przez pojedynczą osobę całości zakresu zarysowanego przez Witruwiusza stało się niemożliwe, a podejście Le Corbusiera do architektury w dużej mierze zostało odrzucone, jako nie spełniające w dostatecznym stopniu ludzkich potrzeb psychologicznych i socjologicznych względem architektury. Postmodernizm, jeśli odrzucić jego formalne igraszki, w istocie postulował zmianę postawy wszechmocnego demiurga na postawę architekta - konsultanta swojego klienta. Postęp w naukach społecznych wywołał niezbędną reakcję także w projektowaniu architektonicznymi i urbanistycznym. Oczywista stała się potrzeba udziału socjologii w kształtowaniu miasta, również psychologia, która wychodząc z laboratorium, znalazła szerokie pole badawcze w skali 1:1, tworząc psychologię architektury (Lenartowicz 1992).

Postępy w dziedzinie neurologii dostarczyły wyrazistych dowodów na wpływ otoczenia na rozwój organizmu ludzkiego i jego zachowanie, głębiej osadzonych niż te otrzymane z obserwacji psychologicznych i socjologicznych. W Stanach Zjednoczonych doprowadziło to do powstania Akademii Neurobiologii dla Architektury¹, która działa na wielu polach,

\footnotetext{
1 ANFA - Academy of Neuroscience For Architecture, założona w 2003 r. przy Instytucie J. Salka w La Jolla w Kalifornii.
} 
poczynając od badań wspólnych dla obu dziedzin, po kursy, warsztaty i publikacje popularne. W tej współpracy neurobiologia jest dostawczynią nowych informacji, odbiorcą zaś - architektura. Utarł się nawet termin neuroarchitecture ('neuroarchitektura'), co sygnalizuje powstanie $\mathrm{w}$ architekturze obszaru zasadniczo i w istotny sposób czerpiącego $\mathrm{z}$ badań naukowych neurobiologii, ale też działającego w drugą stronę, tzn. poprzez nadanie konkretnych cech przestrzeni wpływającego na zachowanie i dobrostan użytkownika (por. szerokie zastosowania w architekturze służby zdrowia) (Lenartowicz i Olszewska 2018).

Janusz Ballenstedt, uczeń Żórawskiego, zaproponował własne rozwinięcie tzw. teorii Żórawskiego. W napisanej pół wieku temu pracy „,Teoria Minimum w architekturze” Ballenstedt (1964) zarysował teoretyczny obraz procesu projektowania jako procesu dokonywania wyboru. Teoria Minimum jest dlań w zasadzie właśnie Teorią Wyboru. Wybór rzeczywiście zawsze jest zasadniczym problemem projektanta, bowiem przystępując do koncypowania możemy/powinniśmy zacząć z różnych punktów widzenia. Ballenstedt proponuje, żeby kryterium wyboru było zużycie energii, rozumiane całościowo. Do zrealizowania zamiaru inwestycyjnego potrzebna jest określona ilość energii: energia włożona przez projektantów (m. in. w pracę mózgu), przez wykonawców, energia jaką zużyją użytkownicy obiektu w całym cyklu jego eksploatacji, wreszcie energia niezbędna do rozbiórki po zakończeniu eksploatacji. Podejście Ballenstedta, który zaleca wybór wariantu możliwości, wiążący się z minimalnym zużyciem energii, wyprzedziło o kilkadziesiąt lat obligatoryjne dzisiaj rozpatrywanie zagadnień środowiskowych wszelkiego rodzaju (przyrodnicze, społeczne, zawodowe, prawne), ekologiczne i ekonomiczne. Ballenstedt chce dyskutować o architekturze w kategoriach mierzalnych, odnosząc się do wydatkowanej energii. Przez energię układu rozumiemy jego zdolność wykonywania pracy. Każdy, kto przeżył projekt, który zdobył jakiś sukces, wie, ile energii kosztowało go osiągnięcie zamkniętej koncepcji. Właśnie energii poświęconej pracy mózgu, który też w chwilach obciążenia wydziela ciepło.

Samo projektowanie jako warsztat architekta, dzisiaj otrzymało szereg komputerowych narzędzi kreślarskich i prezentacyjnych (produktami których można mamić widza - potencjalnego odbiorcę, niekoniecznie odnosząc się do docelowych rezultatów). Ostatnio do repertuaru obowiązkowej wiedzy architekta doszła technologia parametrycznego modelowania informacji o budynku (BIM). W jej reklamie znajdujemy argument, że "zapewnia pracowniom projektowym przewagę konkurencyjną oraz zwiększoną wydajność pracy”. Można stwierdzić, że BIM zapewnia synergię działania dzięki synchronizacji i dostępności wyników w poszczególnych branżach projektowych zaangażowanych w proces projektowania. Takie nowe rozwiązania informatyczne, pozwalają na grupowanie, przetwarzanie i udostępnianie danych o budynku w każdej chwili wszystkim zainteresowanym w projekcie. BIM dotyczy budynku, a co wokół? Co z miastem? Kto zajmie się jego krajobrazem, będzie pilnował i decydował o pięknie?

W fazie III opisano sytuację, kiedy ze względu na wzrost ilościowy problematyka architektury stała się niemożliwa do opanowania przez pojedynczą osobę. W dobie specjalizacji architekt znalazł się w procesie tworzenia i przekształcania przestrzeni życia człowieka jako jeden z wielu: obok urbanisty, konstruktora, inżynierów różnych branż, dewelopera. Żeby zaistniała synergia nie jest jednak ważna liczba uczestników procesu decyzyjnego, ale jakość ich dialogu i jakość przywództwa w zespole. Architekt, poza tym, że jest wykonawcą rysunków budowlanych, został być może jako specjalista od piękna, ale jego pozycja jest nader osłabiona. Pożądana partycypacja wszystkich interesariuszy przyznaje mu miejsce konsultanta, coraz mniej decydenta. Mnożą się przepisy prawne, które przesądzają szereg decyzji, które dawniej mógł/musiał podejmować sam. Tymczasem zawsze pozostaje sprawa wynikowego obrazu i odpowiedzialności za jakość rozwiązania, którą za wszystkich ponosi architekt. 


\section{Faza IV. Utrata jakości kultury budowania. Polska - koniec zawodu architekta?}

Ministrowie kultury krajów europejskich i delegaci sygnatariuszy Europejskiej Konwencji Kulturowej oraz przedstawiciele m.in. Rady Architektów Europy i Rady Europejskiej Planistów Przestrzennych, ICOMOSu i UNESCO, formułując Deklarację Davos 2018, zauważyli, że rozwój sytuacji prowadzi do „dryfowania związanego z utratą jakości zarówno w środowisku zbudowanym jak i otwartych krajobrazach całej Europy, która to utrata jest zauważalna w trywializacji konstrukcji, braku wartości projektowych, w braku troski o zrównoważony rozwój, narastaniu pozbawionego wyrazu rozlewania się zabudowy miejskiej i nieodpowiedzialnym użytkowaniu terenu, a także niszczeniu historycznej tkanki oraz zatracaniu tradycji i tożsamości regionalnych.”2 Centralnym pojęciem Deklaracji jest „kultura budowania”, która w tekście anglojęzycznym jest określona niemieckim terminem Baukultur. Baukultur obejmuje każdą ludzką działalność, która zmienia środowisko zbudowane. Całe środowisko zbudowane ma być rozumiane jako pojedyncza całość, włączając w to każdą zaprojektowaną wartość materialną, która jest osadzona w środowisku naturalnym i się do niego odnosi. Baukultur obejmuje istniejące budynki, w tym zabytki i inne elementy dziedzictwa, jak też projekt i budowę współczesnych budynków, infrastruktury, przestrzeni publicznych i krajobrazów. Deklaracja dotyczy potrzeby dążenia do „Baukultur wysokiej jakości”.

Te uwagi są trafne również w odniesieniu do Polski, gdzie sprawa jakości „kultury budowania" znalazła się w gorszym położeniu niż w krajach zachodnich Europy. Pierwotnej przyczyny tego należy szukać w dziedzictwie moralno-mentalnym lat komunizmu. Można powiedzieć, że w Polsce „kultura budowania” podupadła wraz z wygaśnięciem ważności planów w 1994 r. Od tego czasu panuje sytuacja tyleż złożona, co pozbawiona reguł gry. Brak planów zagospodarowania jest korzystny dla drapieżnych deweloperów. Tworzone w okresie 2016-2018 w ramach przeciwdziałania negatywnym objawom projekty prawa budowlanego idą w założeniach w dobrym kierunku (np. likwidacji instancji jaką jest decyzja o Warunkach Zabudowy i Zagospodarowania Terenu), czy też projekt ułatwienia dostępu do tanich mieszkań na wynajem budowanych przez państwo.

Jest jednak szereg specyficznych czynników hamujących dojście do „wysokiej jakości kultury budowania". Pierwszy czynnik to braki wiedzy i niska świadomość obywatelska społeczeństwa, zachłyśnięcie się własnością prywatną i jej ochroną (m.in. przez 'grodzenie'). Polski inwestor prywatny zapewne oczekuje, że nowy obiekt będzie ładnie wyglądał, ale nie wnika w skomplikowany proces projektowania. Często chodzi mu nie tyle o projekt, co o pozwolenie na budowę, które zapewni, że urząd nie będzie miał pretensji, jeśli sobie coś zbuduje na własnej działce. 'Projekt' staje się niezbędną formalnością, ale niekoniecznie przedyskutowanym zapisem wizji wymarzonego rozwiązania przestrzennego, stąd architekt jest widziany jako dostawca załącznika do wniosku o Pozwolenie na Budowę. Przeciętny Polak nie jest przygotowany do wzięcia udziału w procesie decyzyjnym, który dotyczy przyszłości zbudowanego środowiska, w którym będzie żył sam i jego dzieci. Z tym brakiem wiedzy i nawyków związanych z kulturą budowania zapominamy także o krajobrazie! Krajobraz jest wspólnym dobrem, a więc, zgodnie ze złą tradycją, jest traktowany jako niczyj, stąd nie jest przedmiotem czyichkolwiek starań. W kategoriach prawnych zostawiliśmy go w Polsce samorodnym patriotom, którzy w tym krajobrazie ogrzewają się palonymi oponami i montują bilbordy, które krajobraz przesłaniają nawet w Zakopanem. Krajobraz w mieście jawi się przestrzenią publiczną, o którą też mało kto i mało gdzie dba. Mało dbamy o to, żeby

2 Deklaracja Davos 2018 (Davos $^{2018}$ Declaration), s. 1. 
to, co budujemy miało wartość estetyczną samą w sobie. A już na pewno mało kto patrzy na to, jaki wpływ, chociażby tylko wizualny, ma ten nowy obiekt na otoczenie.

Drugi czynnik związany jest ze studiami architektonicznymi. Co prawda studia te stale cieszą się zainteresowaniem młodzieży, ale w wielu przypadkach chodzi o to, że przypisywany architekturze zawodowy splendor (por.: Faza I) można osiągnąć bez znajomości nielubianej w szkole matematyki czy fizyki, i wystarczy trochę umiejętności rysowania i opanowanie komputera. Czytać i historii uczyć się nie trzeba, byle opanować AutoCAD. System boloński podziału studiów na dwa stopnie z pewnością nie przyczynił się do uzyskania wyższej jakości.

Trzeci czynnik to negowanie potrzeby $\mathrm{i}$ istnienia nauki architektury. W polskich uczelniach technicznych, do których przypisane są wydziały architektury, niejednokrotnie traktuje się je jako zespół ‘artystów', raczej luźno związany z techniką i z „prawdziwymi” badaniami naukowymi. Takie nastawienie prowadzi do propozycji zlikwidowania architektury i urbanistyki jako dyscyplin naukowych. Architektura jako segment budownictwa lądowego nie jest rozwiązaniem prowadzącym do wysokiej jakości. Stan ten jest też wynikiem tego, że w Polsce z niechęcią patrzymy na próby poszerzenia pola widzenia architekta o świadectwa z dziedziny socjo-, psychologii, czy neuronauk. Ich uwzględnienie obciążałoby i spowalniałoby proces decyzyjny.

Czwarty czynnik to tworzone prawo. W projektowanych zmianach prawa, pojęcia 'architektury' i 'architekta', jak też 'urbanisty' niekiedy zanikają. Wspomniany projekt Kodeksu Urbanistyczno-Budowlanego ${ }^{3}$ w pierwszej części jest w nazwie „urbanistyczny”, w drugiej części „budowlany”. Należy zapytać: co jest pomiędzy, pośrodku? Gdzie znikła architektura? Czy ustawa pozbawia architekta odpowiedzialności za przestrzeń życia Polaków? $\mathrm{Z}$ jednej strony świadczy o ustawodawcy braku znajomości sytuacji w krajach rozwiniętych, a z drugiej oznacza skuteczne usunięcie czynnika synergetyzującego procesy dotyczące kształtowania przestrzeni życia, co może oznaczać jej dehumanizację. Znane są problemy z wdrażaniem partycypacji społecznej, która i owszem, znalazła się na właściwym miejscu w polskiej ustawie o rewitalizacji, ale nie podano w niej wykonawców - realizatorów tego godnego poparcia mechanizmu - behawioralnych interwencji publicznych ${ }^{4}$ W dotyczącym tworzonego prawa punkcie jest też definicja ,głównego projektanta sporządzającego akt planowania przestrzennego", którym w świetle projektowanego Kodeksu może być każdy, niekoniecznie urbanista (zawód nieistniejący), w szczególności np. geodeta, geograf i prawnik. Na pewno niekoniecznie architekt. Słowo ,architekt” pojawia się w tym projekcie ustawy dwa razy i to tylko w odniesieniu do innej ustawy: o samorządzie zawodowym architektów i inżynierów budownictwa.

Piąty czynnik to praktyka języka codziennego, deprecjonująca pojęcia „architektury” i ,architekta". W dobie post-wszystkiego, a przede wszystkim post-prawdy, nadużycia językowe są powszechnie tolerowane, a terminy ,architekt” i “architektura”, od dawna już odnoszone są do różnego rodzaju struktur i ich budowania we wszelkich dziedzinach ('architekt porozumienia', 'architektura polityki', 'architektura komputera', 'architektura czegoś tam', ...). W najnowszych zastosowaniach wiąże się je z negatywnymi zjawiskami. Marta Urzędowska w artykule „Nowoczesny jak Saudyjczyk”5 zatytułowała podrozdział: „Architekt dwóch

\footnotetext{
3 Projekt z dnia 30 września 2016 r. Ustawa Kodeks Urbanistyczno-Budowlany (nr 12290 463). Por. także: posiedzenie nadzwyczajne Komisji Urbanistyki i Architektury PAN O/Kraków na temat: "Podstawy prawne architektury i urbanistyki w Polsce. Dyskusja nad projektowanymi zmianami ustawowymi” (6 czerwca 2017) oraz: seminarium Komisji Architektury i Urbanistyki PAN O/Wrocław na temat: „Kodeks UrbanistycznoBudowlany. Szanse i zagrożenia" (8 czerwca 2017) - publikacja w przygotowaniu.

4 Por. Lenartowicz (2016).

5 Gazeta Wyborcza, Magazyn Świąteczny, sobota-niedziela, 4-5 listopada 2017, s. 17.
} 
awantur”, odnosząc tytuł 'architekt' do księcia Muhammada walczącego zbrojnie z wpływami Iranu w Jemenie kosztem katastrofy humanitarnej. Dalej w tekście napotykamy też zdanie: "MBS jest też uznawany za architekta rozpętanej tego lata awantury z Katarem.” Bez komentarza. Ale zauważmy, że 'architekt' buduje, 'architektura' zaś służy ludziom, a nie niszczeniu i pozbawianiu życia kogokolwiek.

\subsection{Studium przypadku (Polska)}

$\mathrm{Na}$ poprzedniej konferencji autor „reklamował” krakowskie osiedle mieszkaniowe „Ruczaj, czyli pierwsze na świecie eksperymentalne osiedle bez zieleni”6, które to określenie opisuje betonowy krajobraz, sarkastycznie przeciwstawiając się inicjatywom wprowadzenia zieleni w osiedlu. Również w Krakowie, przedmiotem dyskusji publicznej w 2018 r. stało się osiedle Nowe Czyżyny. Urzędnicy miejscy stwierdzili, że „dzielnica Czyżyny ma zbyt wiele [!] $\mathrm{m}^{2}$ zieleni na 1 mieszkańca". Jak się okazało, dzieje się tak za sprawą istnienia Parku Lotników Polskich, służącego całemu miastu, który jako areał zielony bezmyślnie został przypisany tylko jednej z dzielnic. To w niej osiedle Nowe Czyżyny, jako sypialnia dla kilku tysięcy ludzi, pasożytuje na starych, już istniejących osiedlach. Nie tylko tutaj powszechną praktyką stało się wciskanie nowych inwestycji do wnętrz blokowych terenów zieleni ${ }^{7}$. Deweloperzy budują domy mieszkalne, bez usług, bez parkingów. Ten schemat działania jest efektem agresywnej polityki - „nie rozlewamy się poza granice miasta, ale budujemy w nim, upychając możliwie wiele mieszkań na minimalnej przestrzeni”. Nowe domy/bloki powstają kosztem dobra okolicznych starych mieszkańców, ich komfortu.

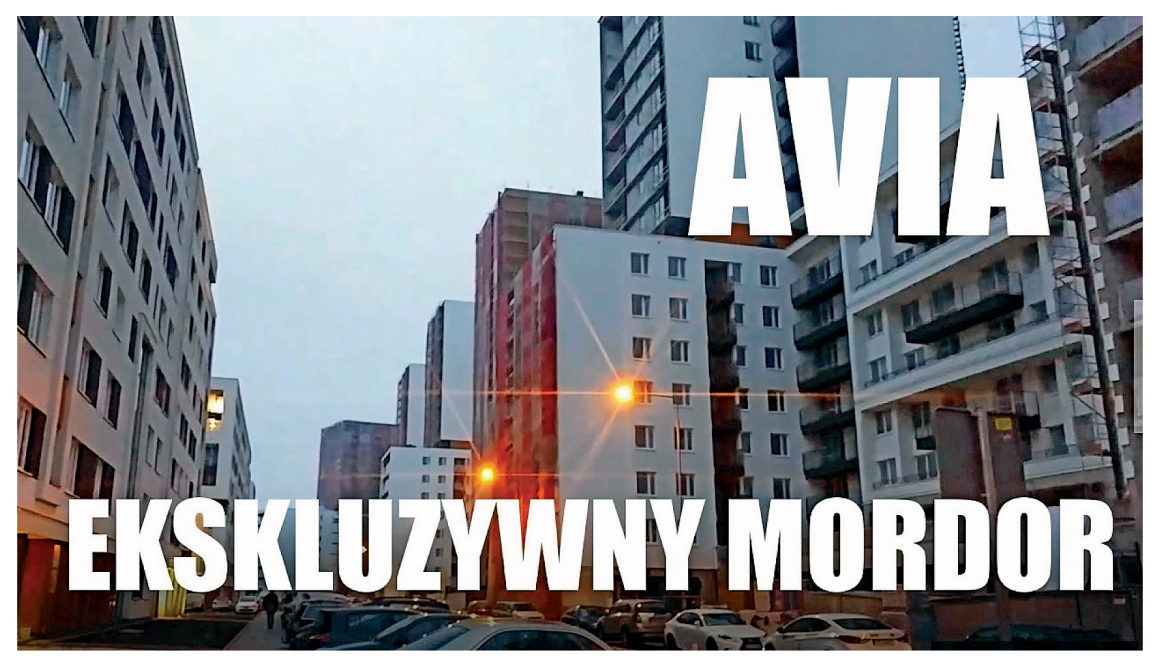

Il. 6. Osiedle Avia, Nowe Czyżyny w Krakowie. Czołówka filmiku satyrycznego. 'DziadostwO TV'. 23 marca 2017

Nowe inwestycje uszczuplają istniejące zasoby zieleni, które dla zasiedziałych mieszkańców nie są pustą przestrzenią, ale miejscem, które ma wartość emocjonalną. Zatrudniony przez dewelopera projektant nie przewidział zieleni dla mieszkańców osiedla, które niektó-

\footnotetext{
6 Lenartowicz (2016).

7 Radłowska (2017), s. 5.
} 
rzy już nazywają Mordorem ${ }^{8}$ (por. il. 06). Teren nie ma Miejscowego Planu Zagospodarowania, więc miasto sprzedaje przyszłych mieszkańców wraz z terenem i rosnącymi drzewami w ręce inwestora. Wydział Architektury Urzędu Miasta jest bezbronny, nawet wydając decyzję o WZiZT na ogołocony z zieleni teren osiedla.

W fazie IV, poza zauważalnymi w całej Europie brakami wysokiej jakości Baukultur, w odróżnieniu od Europy, w Polsce następuje dezintegracja zawodu. To architekt otrzymuje wykształcenie z dozą historii sztuki i estetyki. On powinien być odpowiedzialny za jakość naszego środowiska życia. Tymczasem inni przejmują pałeczkę dotąd dzierżoną przez architekta. Architekci-urbaniści doczekali się prawnej likwidacji swojej profesji. W skali architektonicznej dominuje tzw. deweloper. W takiej sytuacji architekt poddawany presji, narażony na pokusy przez inwestora - poddaje się. Maleje rola etyki zawodowej. Zawód, który należał do 'wyższej użyteczności publicznej', a obecnie pretenduje do bycia 'zawodem zaufania publicznego' nie jest wystarczająco znaczący, żeby przyjąć odpowiedzialność za kulturę budowania. Przyczyny są różne: specjalizacja prowadząca do izolacji; estetyka przegrywająca z ekonomią; problemy nauczania; problemy etycznego zachowania w zawodzie; sprzeczności w kształtowaniu prawa, które jest pisane przez prawników dla prawników zamiast dla społeczeństwa; wreszcie świadomość społeczeństwa i brak społeczeństwa obywatelskiego.

\section{Faza V. Zwiastun optymizmu. Anna Cioch bierze sprawę we własne ręce... Świadomy obywatel domyka efekt synergetyczny}

W sytuacji gdy architekci o nich zapomnieli, mieszkańcy muszą swoje sprawy brać we własne ręce. Konieczność wspólnego działania, a zatem wprost rozumianej synergii w walce o własne dobro zaczyna dojrzewać wśród najbardziej poszkodowanych. Pozostańmy przy opisanych Czyżynach ${ }^{9}$. Pod rozbudowę jego części, osiedla Avia (nazwa atrakcyjna - dobry element reklamy, świadczy o tym, że osiedle znajduje się w pobliżu d. krakowskiego lotniska i Muzeum Lotnictwa Polskiego w Krakowie!) deweloper chce zabudować działkę, na której rośnie 51 drzew. Tę zieleń zamierza oczywiście wyciąć. Mieszkańcy wielokrotnie prosili, walczyli w urzędzie, a także walczyli w sądzie. Magistrat nie był w stanie zareagować i ewentualnie zablokować kolejnych inwestycji planem zagospodarowania. W negocjacjach z właścicielem terenu zielonego - deweloperem, mieszkańcy chcą brać udział jako równoprawny partner.

Wobec braku architekta, który przewidziałby ogólnie dostępną zieleń osiedlową, wkracza pani Anna Cioch, która nie jest architektem. Zakłada stowarzyszenie Wspólne Czyżyny, działa jako behawioralny interwent przestrzenny. Dziś stwierdza:

„... nie można zapomnieć o kontekście, czyli wielkim osiedlu, które powstało w Czyżynach właśnie za zgodą urzędników i gdzie wycięto mnóstwo drzew. (...) Mam nadzieję, że i my będziemy inspiracją dla dużej grupy mieszkańców, którzy też borykają się z brakiem zieleni oraz zbyt gęstą zabudową."

Zapewne tych 51 drzew, dzięki pani Annie Cioch zostanie uratowanych. Można jednak zapytać, kto jest projektantem osiedla i dlaczego zapomniał o zieleni dla mieszkańców młodego osiedla? Trzeba też zapytać, kto wydał niezbędne pozwolenia na taką intensywność zabudowy, która pozbawia mieszkańców zieleni wewnątrz osiedla? W Kodeksie Etyki Zawodowej Architekta (KEZA 2005) nie ma mowy o procencie zieleni jaki powinien przypadać na

\footnotetext{
8 Użyta przez J.R.R. Tolkiena w powieści The Lord of the Rings nazwa Mordor, wywodzi się ze staroangielskiego rzeczownika 'mordor', co znaczy „śmiertelny grzech” albo wprost „morderstwo”.

9 Rogozik (2017), s. B2.
} 
jednego mieszkańca miasta, ale jest mowa o konieczności rzetelnego wykonywania zawodu. Smutne. Architekt nieuważny nie budzi zaufania, zaufania publicznego. Woli, jak się wydaje, unikać odpowiedzialności. Zanik zawodu?

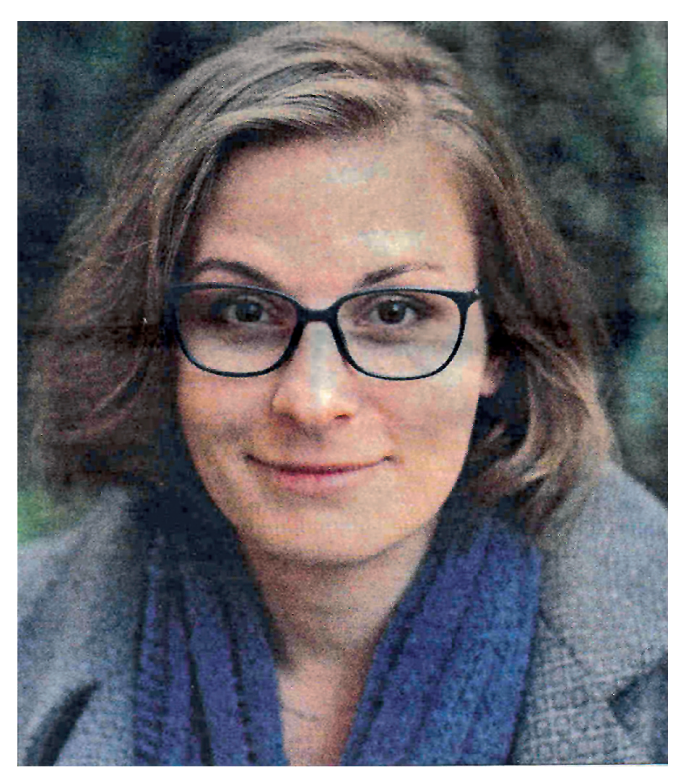

I1. 7. Anna Cioch, założycielka stowarzyszenia Wspólne Czyżyny. Fot. Michał Gąciarz. Według: Dziennik Polski, Kronika Krakowska, 3-4 czerwca 2017, s. B2

Ludzie sami się organizują. Talent społeczny, zrozumienie potrzeb ludzkich zastępuje wykształcenie architektoniczne. Pojawia się obywatel. A co zrobili wykształceni architekci, czy nie są obywatelami? A kodeks zawodowej etyki?

\section{Co dalej?}

„Wszystko na świecie jest możliwe (Pesymista: - Już gorzej być nie może. Optymista: - Może, może!).”10

Istota zawodu architekta wynika z synergii, co autor próbował udowodnić. Nie sposób być architektem nie znając historii kultury, historii architektury, historii sztuki, budownictwa, nie posiadając umiejętności analizowania miejsca, umiejętności współpracy z projektantami innych specjalności, nie będąc 'patriotą pejzażu' (por. Lenartowicz 2016), nie umiejąc czy nie chcąc rozmawiać z przyszłymi użytkownikami. Architekt powinien znać się ,na wszystkim", z czego wynika, że nie może się wgłębiać we wszystkie problemy związane z kształtowaniem środowiska, ale musi być ich wszystkich świadomy, żeby móc całościowo koordynować działania. Względnie płytka znajomość problematyk związanych z architekturą traktowaną jako kształtowanie przestrzeni, nie umniejsza konieczności szerokiego spojrzenia na świat, jest związana z synergicznym charakterem zawodu architekta.

Wypada na koniec zastanowić się nad powrotem do synergii w kształtowaniu przestrzeni nas otaczającej. Spójrzmy na symptomy poprawy, jakie można zauważyć w Polskiej

${ }^{10}$ Stefan Kisielewski „Kisiel”, Dzienniki, Iskry 1996, s. 101. 
kulturze budowania, nawiązując do czynników, które zostały przedstawione jako stanowiące o słabości i braku synergii. Gdzie szukać optymizmu w tych warunkach?

Świadomość sprawczości w społeczeństwie, w polskich warunkach co prawda słabo, ale dojrzewa. Przykład Anny Cioch i jej stowarzyszenia oznacza zaczątki społeczeństwa obywatelskiego. Idea obywatelstwa porywa stopniowo coraz więcej osób. To one organizują ruchy miejskie, akcje miejskie, grupy lokalne, które zaczynają wywierać nacisk i potrafią wtargnąc nieproszone w sytuacjach decyzyjnych. Dotąd niedoceniane, zawsze niechciane, odrzucane i wyśmiewane, one tylko mogą stać się partnerem architekta czy urbanisty w tworzeniu lepszej przestrzeni osiedla, domu, czy mieszkania. Przyszli użytkownicy, wiedzący czego chcą i znający lepsze rozwiązania, nie pozwolą, również architektom, na psucie środowiska zbudowanego w przyszłości.

Trzeba też zauważyć szereg coraz liczniejszych publikacji poświęconych sprawom i jakości środowiska zbudowanego, powstawania ruchów miejskich, a także organizacji, które są w stanie podjąć współpracę z organami samorządowymi. Uświadamianiu zwykłego obywatela służą także popularne konkursy zarówno na najlepszą, jak i na najgorszą realizację roku - jeden z inwestorów nagrodzonych tą ostatnią, zdemontował kolumienki które dodał do istniejącego modernistycznego obiektu.

Szersze wykorzystanie wyników badań nauk, takich jak socjologia, psychologia i neurobiologia dla architektury oraz postępem w dziedzinie informatyzacji, a także naukowe wspieranie budowania świadomości obecnych i przyszłych użytkowników miasta, osiedla, budynku i mieszkania, wypromuje partnera rozumiejącego problemy kształtowania i jakości środowiska zbudowanego.

Ruszyły konsultacje publiczne projektu z dnia 1 września 2017 r. Ustawy o architektach, inżynierach budownictwa oraz urbanistach. Zgodnie z przedstawionymi propozycjami zawód urbanisty będzie mógł być wykonywany tylko i wyłącznie przez osoby, które będą wpisane do centralnego rejestru osób posiadających prawo do wykonywania zawodu urbanisty. To brzmi obiecująco biorąc pod uwagę wcześniejszy fakt rozwiązania Izby Urbanistów. Ważne też jest, że w tytule ustawy występuje postać ,architekta”.

Aktualną społecznie inicjatywą rządową jest projekt zwany Mieszkanie plus, dzięki któremu Polacy mają otrzymać dostęp do tanich lokali na wynajem. Cieniem w tej sprawie jest to, że w marcu 2018 r. rząd zaprojektował Ustawę o ułatwieniach w inwestycjach mieszkaniowych. Na podstawie projektowanych przepisów inwestorzy będą mogli budować niezależnie od ewentualnie już uchwalonych miejscowych planów zagospodarowania, jako że Ustawa stoi wyżej od prawa lokalnego. W dodatku możliwość interwencji rady gminy została znacznie ograniczona; a co więcej „nie trzeba brać pod uwagę głosów mieszkańców”11. Można też budować bez ograniczeń na terenach, gdzie planu nie ma.

Projekt Kodeksu Urbanistyczno-Budowlanego (2017), wcześniej tu przedstawiony, wprowadza, a właściwie przywraca pewne standardy urbanistyczne. Czy chcemy ten Kodeks wycofać? Grożącą anarchię przestrzenną (de-synergizację przestrzeni) dostrzegł już Komitet Przestrzennego Zagospodarowania Kraju Polskiej Akademii Nauk w swojej opinii. Krytycznie patrzą na otwierające się możliwości również niektórzy deweloperzy: „nasi klienci nie będą zadowoleni, gdy nagle za oknem wyrośnie im kolejny budynek, niezgodny z dotychczasową wizją"12.

Uwagi odnoszące się do Polski są zarazem tożsame z ustaleniami Deklaracji zebranych w Davos ministrów kultury: „wysokiej jakości Baukultur może wyrosnąć jedynie

\footnotetext{
11 Jakub Nowotarski (“Akcja Miasto”), [w:] Kokoszkiewicz (2018).

12 Kokoszkiewicz (2018).
} 
w kontekście interdyscyplinarnego dyskursu i poprzez wielopoziomową i międzysektorową współpracę między politykami, kompetentnymi władzami i profesjonalistami. Ponieważ ta współpraca obejmuje twórcze, funkcjonalne i społeczne aspekty, wszystkie relewantne dyscypliny i profesjonaliści muszą brać w niej udział na równej stopie. Jednym z kluczowych przykładów instrumentu służącego wspieraniu wysokiej jakości są interdyscyplinarne i szeroko debatowane konkursy. Dla osiągnięcia sukcesu, wysokiej jakości Baukultur wymaga także partycypacji społeczeństwa obywatelskiego i dysponującej wiedzą uwrażliwionej publiczności”. ${ }^{13}$

Musimy być tego świadomi, żeby zachować synergiczny charakter organicznie związany z zawodem architekta. Musimy architektom zapewnić dobre prawo, ale też oni sami muszą zdobywać aktualną wiedzę związaną z ich profesją. architekci powinni (móc) spełniać swoje synergetycznie zdefiniowane zawodowe zadania w oparciu o aktualną wiedzę techniczną i ekologiczną, ale też muszą (umieć) wykorzystywać współczesną wiedzę socjologiczną, psychologiczną i neurobiologiczną.

\section{Literatura}

[1] Ballenstedt J. Teoria Minimum w architekturze. Teka Komisji Urbanistyki i Architektury PAN O/ Kraków, tom XLV, rok 2017, s. 29-74.

[2] Deklaracja Davos (Davos ${ }^{2018}$ Declaration), Towards a high quality Baukultur for Europe. Konferencja ministrów kultury UE, 20-22 stycznia 2018, Davos. https://davosdeclaration2018.ch/ media/Davos_Declaration_2018-23.01/2018.pdf.

[3] Kodeks Etyki Zawodu Architekta. SARP i Izba Architektów RP, 2005.

[4] Kodeks Urbanistyczno-Budowlany, 2017, projekt nr 12290463 z dnia 30 września 2016: legislacja.gov.pl.

[5] Kokoszkiewicz, M. Buduj, gdzie kto może. Gazeta Wyborcza, Piątek, 30 marca 2018, s. 8.

[6] Komisja Urbanistyki i Architektury PAN O/Kraków (2017) Stanowisko w sprawie projektu ustawy pt.: Kodeks Urbanistyczno-Budowlany w odpowiedzi na zaproszenie Przewodniczącego Komisji Architektury i Urbanistyki PAN Oddz. we Wrocławiu, nadzwyczajne posiedzenie w dniu 6 czerwca 2017.

[7] Le Corbusier. Vers une architecture. Les Editions G. Crès et Cie. 1923. Wyd. polskie: W stronę architektury. Centrum Architektury / Fundamenty, Bęc Zmiana, Warszawa 2012.

[8] Le Corbusier. Urbanisme. Paris, édition originale: G. Crès, collection L'Esprit nouveau, 1924. Wyd. polskie: Urbanistyka. Centrum Architektury / Fundamenty, Bęc Zmiana, Warszawa 2015.

[9] Lenartowicz J.-K. O psychologii architektury. Politechnika Krakowska, Kraków, 1994.

[10] Lenartowicz J.-K. Synergetyka a planowanie urbanistyczne i projektowanie architektoniczne. Budownictwo i Architektura 16(1) (2017) 199-212.

[11] Lenartowicz J.-K., Olszewska N. Neuro-architektura. Moda czy początek przełomu w architekturze? Zastosowania neurobiologii w projektowaniu architektonicznym. X Interdyscyplinarna Konferencja Naukowa TYGIEL 2018 - Interdyscyplinarność kluczem do rozwoju”. Lublin 1718 marca 2018, Abstrakty, s. 32-33.

[12] Radłowska R. Nowe Czyżyny - narośl na mieście. Gazeta Wyborcza Kraków, Magazyn Krakowski, Wydarzenia, piątek 2 czerwca 2017, s. 5. R. Radłowska rozmawia z Jackiem Gądeckim.

[13] Rogozik, M. Mieszkańcom Czyżyn coś się od miasta należy. Dziennik Polski, Kronika Krakowska / Z drugiej strony. Rozmowa Kroniki, sobota-niedziela 3-4 czerwca 2017, s. B2. Autorka rozmawia z Anną Cioch, założycielką stowarzyszenia Wspólne Czyżyny.

[14] Witruwiusz. O architekturze ksiąg dziesięć. PWN, Warszawa 1956.

${ }_{13}$ Deklaracja Davos 2018, punkt 16., s. 4. 
[15] Żórawski J. Rzeźba-architektura-malarstwo. Problematyczna geneza. Teka Komisji Urbanistyki i Architektury PAN O/Kraków, 1997.

[16] Żórawski J. O budowie formy architektonicznej. Arkady, Warszawa 1962.

[17] Żórawski J. (1962b) „Postawy w architekturze”. Architektura nr 9, Zeszyt Naukowy nr 5, Politechnika Krakowska, Kraków; tutaj za: J. Żórawski, Wybór pism estetycznych (pod red. D. Jurusia). Universitas, Kraków 2008.

\title{
Architect as a synergist
}

\section{J.-Krzysztof Lenartowicz}

Faculty of Civil Engineering and Architecture, Lublin University of Technology Faculty of Architecture, Cracow University of Technology,e-mail: j.lenartowicz@pollub.pl

\begin{abstract}
The article presents a critical analysis of the scope of the work and status of the architect that changes over time, along with pointing to the current situation in Poland. The scope of the work of the vitruvian Architectus spanned from the planning of cities to the construction of clocks; the entirety of the knowledge of engineering was to be mastered by him. Architecture was treated as the Mother of the Arts. The result of the synthesis of the arts was the XIX-century Gesamtkunstwerk. Żórawski (1961) wrote of the organic link between architecture and the other arts. Le Corbusier (1929) defined architecture as the learned game of forms assembled in light, essentially limiting it to its visible form. Today, mastering the entirety of the discipline by a single individual is impossible. The architectural profession has begun to split into fragments and specialisations. From architects there have come urban planners, structural engineers, landscape architects, ecologists and lately even intermediaries between stakeholders (the users and the design team), serving to carry out behavioural public intervention - all of them are associated with architecture. The necessary scope of the analysis now includes all manners of environmental issues (natural, social, professional and legal ones) as well as ecological and economic ones. Design itself has received digital coordination, modelling, drafting and presentation tools. What say does an architect have in Poland today? As an urban planner, he has been struck from the law (2014), as an architect he exists in the professional association chamber, but he no longer has mastery over the other arts. The Urban Planning and Construction Code Act (2017) has left out building clocks, but it also does not mention the architect. Construction practice confirms that the synergistic understanding of the profession has been forsaken, as well as the fall of the creativity and moral responsibility of the members of a - nominally - profession of public trust. In current Polish journalist post-language the words 'architecture' and 'architect' are applied in extremely contradictory cases, like "architect of the massacre in Yemen". Where has architecture gone?
\end{abstract}

Keywords: architectural profession, definition of architecture, visual arts, law, beauty. 
